Jurnal Geografi, Edukasi dan Lingkungan (JGEL) Vol. 3, No. 2, Juli 2019:62-68

P-ISSN: 2579-8499; E-ISSN: 2579-8510

Doi: https://doi.org/10.29405/jgel.v3i2.2948

Website: http://journal.uhamka.ac.id/index.php/jgel

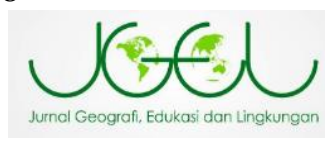

\title{
Perhitungan Luas Atap Untuk Analisis Daya Tampung Pengungsian Menggunakan SIG Di Kecamatan Jatiyoso Kabupaten Karanganyar
}

\author{
Farida Nurul Yusrina*, Linta Alfi Fahmi, Edgar Jordan, Deviana Kusuma Putri, \\ Mulyani, dan Alfi Okta Syahputra \\ Program Studi Pendidikan Geografi, FKIP Universitas Muhammadiyah Surakarta, Jawa \\ Tengah, Indonesia
}

*E-mail: a610162002@student.ums.ac.id

Received: 03012019 / Accepted: 11042019 / Published online: 30072019

\begin{abstract}
ABSTRAK
Karanganyar merupakan salah satu Kabupaten di Provinsi Jawa Tengah yang sering mengalami bencana longsor. Menurut Data BPBD Karanganyar menyatakan bahwa selama tahun 2017 tercatat terdapat 80 kejadian bencana tanah longsor. Kecamatan Jatiyoso merupakan salah satu Kecamatan yang memiliki tingkat kerawanan longsor sedang hingga tinggi. Daya tampung pengungsian menjadi aspek penting yang harus diketahui dalam perencanaan lokasi pengungsian. Berdasarkan hal tersebut, maka penelitian ini bertujuan untuk mencari potensi daya tampung fasilitas umum untuk pengungsian yang ada di Kecamatan Jatiyoso. Penelitian ini menggunakan metode perhitungan luas atap bangunan dengan menggunakan Sistem Informasi Geografis, yang dianalisis dengan menggunakan pendekatan spasial. Berdasarkan hasil analisis, diperoleh daya tampung fasilitas umum di Kecamatan Jatiyoso terdapat sebanyak 6.960 jiwa atau $16 \%$ penduduk dapat tertampung di pengungsian, sedangkan jumlah penduduk sebesar 36.465 jiwa. Berdasarkan hal tersebut, maka sebanyak 29.505 jiwa (84\%) penduduk tidak tertampung ketika terjadi bencana longsor. Daya tampung fasilitas pengungsian tidak dapat menampung keseluruhan penduduk yang terdampak bencana, karena jumlah shelter yang tidak sebanding dengan jumlah penduduk yang ada. Kurangnya daya tampung shelter untuk pengungsian seharusnya dapat menjadi bahan pertimbangan pihak-pihak tertentu untuk lebih memperhatikan fasilitas-fasilitas sebagai tempat pengungsian.
\end{abstract}

Kata kunci : Shelter, Daya Tampung, Luas Atap, SIG

\section{ABSTRACT}

Karanganyar is one of the regencies in Central Java Province which often experience landslide disaster. The data was published by BPBD Karanganyar stated that during 2017 there were 80 landslides occurring. Jatiyoso District is one of the Districts that has a moderate to high level of landslide susceptibility. The displacement capacity is an important aspect that must be known in the planning of evacuation sites. Based on this, the aim of this research is to find the potential capacity of public facilities for refugees in Jatiyoso District. This study used the method of calculating building roof area by using Geographic Information Systems, which analyzed using a spatial approach. The result of this research is the capacity of public facilities in Jatiyoso District there are 6,960 people or $16 \%$ of the population can be accommodated in refugees while the population is 36,465 people. Based on it, there are 29,505 people (84\%) are not accommodated. The capacity of the evacuation facility cannot accommodate the entire population affected by the 
disaster, because the number of shelters is not comparable to the existing population. The lack of shelter capacity for evacuation should be considered by certain parties to pay more attention to facilities as a place of refuge.

Keywords : Shelter, Capacity, Roof Area, GIS

\section{PENDAHULUAN}

Bencana longsor menempati peringkat ke-lima dari keseluruhan jumlah kejadian bencana yang sering terjadi di Indonesia, dengan rata-rata jumlah kejadian 92 kali per tahun (Karnawati dalam Setiawan, 2014). Selama kurun waktu 15 tahun, yaitu dari tahun 1990 sampai dengan 2005, jumlah kejadian longsor di Pulau Jawa sebanyak 1.500 kali (Setiawan, 2014).

Karanganyar merupakan salah satu kabupaten di Propinsi Jawa Tengah yang sering mengalami bencana longsor. Lokasi bencana tanah longsor di Kabupaten Karanganyar tersebar di 9 (sembilan) Kecamatan yaitu Tawangmangu, Karangpandan, Matesih, Ngargoyoso, Jatiyoso, Jumapolo, Jenawi, Kerjo dan Jumantono, dari beberapa lokasi tersebut lokasi yang lebih rawan bepotensi longsor menengah hingga tinggi yang terdapat pada Kecamatan Jatiyoso (Prawiradisastra, 2008)

Data yang diterbitkan oleh BPBD Karanganyar menyatakan bahwa, selama tahun 2017 tercatat kejadian bencana longsor 80 kejadian, angin ribut 24 kejadian, banjir 7 kejadian dan kebakaran 36 kali. Data tersebut menunjukkan bahwa bencana utama yang paling sering terjadi di Kabupaten Karanganyar adalah tanah longsor.

Bencana tanah longsor merupakan jenis bencana geologi yang sering terjadi di Indonesia. Tanah longsor merupakan proses perpindahan atau pergerakan massa tanah dengan arah miring atau vertikal dari kedudukan semula sebagai akibat gaya berat. Longsor dapat terjadi apabila intensitas curah hujan tinggi, pelapukan tebal, kondisi lereng yang miring hingga terjal, batuan dan struktur geologi bervariasi dan penggunaan lahan yang kurang sesuai dengan karakteristik lahannya (Sutikno dalam Setiawan, 2014).

Becana yang terjadi dapat menyebabkan kerugian dan korban jiwa. Besar kecilnya kerugian akibat bencana alam dapat disebabkan oleh dua faktor, yaitu skala kejadian dan pengetahuan tentang bencana alam itu sendiri yang meliputi tipe, karakteristik, dan agihannya (Peraturan Kepala BNPB No. 02 Tahun 2012).

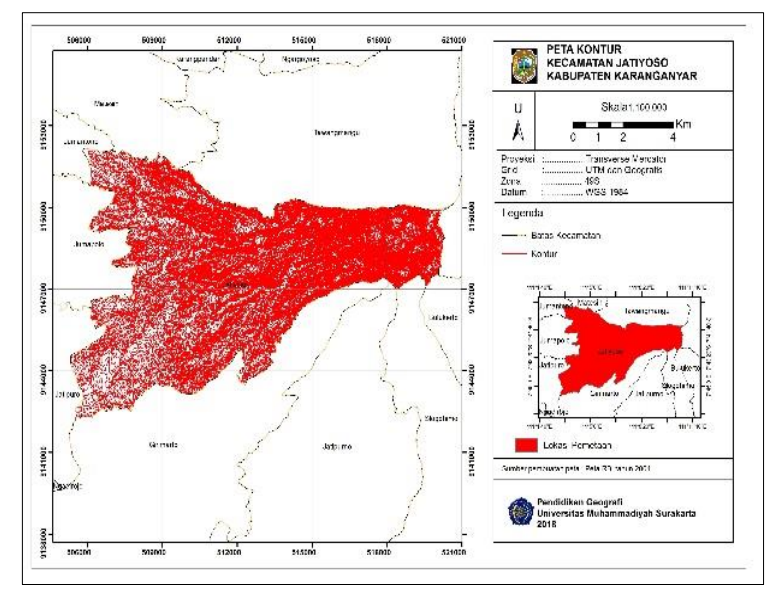

Gambar 1. Peta kontur Kecamatan Jatiyoso

Kecamatan Jatiyoso memiliki karakteristik kontur yang rapat hampir disetiap wilayah, dapat dilihat dari Gambar 1. bahwa kerapatan kontur paling tinggi pada daerah timur hingga ke bagian tengah Kecamatan Jatiyoso yang menunjukkan daerah tersebut termasuk daerah yang curam. Daerah barat Kecamatan Jatiyoso atau daerah paling ujung juga memiliki kontur yang rapat namun relatif lebih renggang jika dibandingkan daerah timur. Karakteristik kontur yang rapat pada Kecamatan Jatiyoso menunjukkan bahwa sebagian besar daerah tersebut curam 
sehingga rawan terhadap bencana tanah longsor.

Pengungsian merupakan salah satu aspek terpenting dalam penanganan korban bencana. Penentuan tempat Evakuasi merupakan salah satu upaya yang dilakukan untuk menjamin keselamatan masyarakat yang terdampak bencana (Fernando, Sujatmo, \& Hendri, 2017). Pengungsi merupakan orang yang berada dalam keadaan yang sangat rentan. Pengungsi berhak atas sejumlah hak seperti perlindungan dan bantuan yang disesuaikan dengan keadaan masingmasing. Pada prinsipnya perlindungan pengungsi merupakan tanggung jawab setiap negara (Hadi \& Hadiguna, 2016).

Kelayakan tempat evakuasi: Tempat evakuasi seharusnya dipersiapkan dengan kondisi yang layak. Kelayakan tempat evakuasi dapat dilihat dari beberapa aspek seperti ketersediaan sarana dan prasarana, keamanan, berdasarkan kriteria tempat yang paling aman, mudah dijangkau, dan mempunyai daya tampung memadai serta relatif tinggi datarannya (Yayasan Pengabdi Masyarakat (YPM) dan Japan International Cooperation Agency (JICA), 2011). Berbagai permasalahan dapat timbul akibat bencana yang terjadi, seperti: masalah kesehatan akan semakin banyak pada saat dihadapkan pada ketersediaan fasilitas pengungsian dengan daya tampung terbatas dan sanitasi yang buruk (Buletin Info Krisis Kesehatan, 2012).

Kehidupan pengungsi sangat bergantung pada ketersediaan daya tampung yang disediakan pemerintah di tempat pengungsian. Daya tampung pengungsian juga menjadi aspek penting yang harus diketahui dalam perencanaan lokasi pengungsian. Perhitungan luas bangunan merupakan salah satu pendekatan yang dapat digunakan untuk mengetahui daya tampung pengungsian setiap bangunan. Berdasarkan hal tersebut, maka penelitian ini berusaha untuk mengidentifikasi daya tampung pengungsian yang ada di Kecamatan Jatiyoso mengunakan Sistem Informasi Geografis.

Sistem Informasi Geografis (SIG) merupakan suatu sistem informasi berbasiskan komputer untuk menyimpan, mengelola dan menganalisis, serta memanggil data bereferensi geografis yang berkembang pesat. Manfaat dari SIG adalah memberikan kemudahan kepada para pengguna atau para pengambil keputusan untuk menentukan kebijaksanaan yang akan diambil, khususnya yang berkaitan dengan aspek keruangan (Setiadi, 2013).

\section{METODE PENELITIAN}

\section{Waktu dan Lokasi Penelitian}

Waktu untuk penelitian ini selama 4 bulan di mulai dari bulan September hingga Desember Tahun 2018. Penelitian dimulai dari tahap persiapan sampai pembuatan laporan penelitian. Lokasi penelitian dilakukan di Kecamatan Jatiyoso Kabupaten Karanganyar (Gambar 2) .

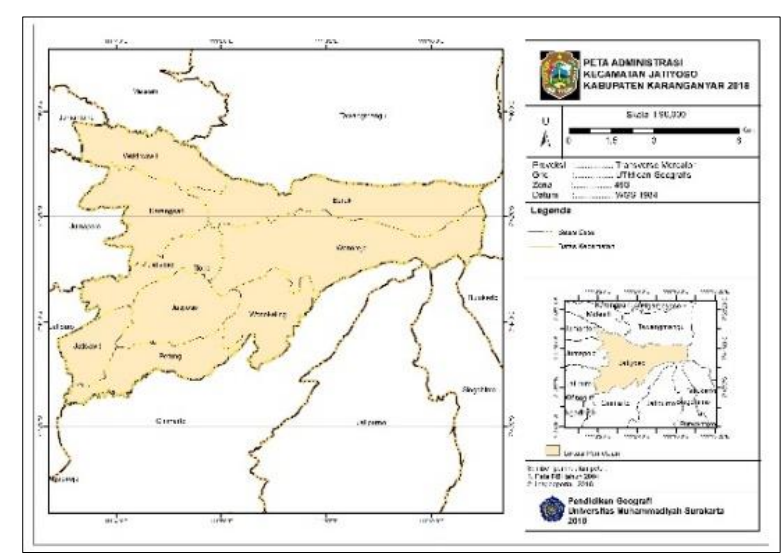

Gambar 2. Peta Lokasi Penelitian

\section{Alat dan Bahan}

Alat dan bahan yang diguankan dalam penelitian ini disajikan pada Tabel 1 . 
Tabel 1. Alat dan Bahan Penelitian

\begin{tabular}{|l|l|}
\hline \multicolumn{1}{|c|}{ Alat dan Bahan } & \multicolumn{1}{|c|}{ Fungsi } \\
\hline Aplikai ArcGIS & Pengolahan data \\
\hline Kamera & Dokumentasi \\
\hline Aplikasi TNP & $\begin{array}{l}\text { Menandai titik } \\
\text { koordinat fasilitas } \\
\text { pengungsian }\end{array}$ \\
\hline Data BPS & $\begin{array}{l}\text { Data yang } \\
\text { digunakan untuk } \\
\text { penelitian }\end{array}$ \\
\hline $\begin{array}{l}\text { Peta RBI dan } \\
\text { Citra }\end{array}$ & $\begin{array}{l}\text { Bahan } \\
\text { pengolahan peta }\end{array}$ \\
\hline
\end{tabular}

\section{Jenis Penelitian}

Jenis penelitian yang digunakan pada penelitian ini yaitu menggunakan metode penelitian deskriptif kualitatif, dengan teknik analisis metode luas atap yang digunakan untuk menghitung besarnya daya tampung shelter.

\section{Metode Pengumpulan, Pengolahan, dan Analisis Data}

Data yang diperoleh dan dikumpulkan dalam penelitian ini adalah data primer yaitu data yang diambil langsung pada sumbernya seperti pada saat observasi lapangan. Pengumpulan data menggunakan GPS untuk memplotting koordinat fasilitas umum di Kecamatan Jatiyoso.

Data sekunder adalah data-data pendukung seperti buku, jurnal, artikel, Citra Google Earth, Badan Pusat Statistik, dan peta kerawanan bencana longsor. Dokumentasi digunakan untuk mengabadikan gambar di wilayah penelitian.

Teknik pengumpulan data pada penelitian ini menggunakan metode observasi dan dokumentasi. Observasi dilakukan untuk mengetahui objek penelitian secara langsung seperti titik koordinat, keaadaan fisik wilayah, kemudian dokumentasi diambil saat sebagai bukti adanya penelitian yang dilakukan.
Analisis data pada penelitian ini menggunakan metode perhitungan luas atap bangunan dengan menggunakan Sistem Informasi Geografis. Analisis geografi yang digunakan adalah analisis spasial yang melihat pola sebaran shelter dan daya tampung di Kecamatan Jatiyoso. Daya tampung shelter berarti kemampuan shelter yang dapat digunakan untuk menerima atau kemampuan ditempati korban. Teknik analisis untuk melihat seberapa besar jumlah korban yang dapat ditampung oleh shelter yaitu dengan menggunakan rumus menurut United Nations High Commission of Refugees (UNHCR) yaitu kebutuhan ruang evakuasi sementara adalah $3.5 \mathrm{~m}^{2}$ per orang, artinya daya tampung sebesar $3.5 \mathrm{~m}^{2}$ dapat menampung satu orang.

$$
\text { daya tampung }=\frac{\text { Luas atap bangunan }}{3.5 \mathrm{~m}^{2}}
$$

\section{HASIL DAN PEMBAHASAN}

Berdasarkan Gambar 3 dapat diketahui Kecamatan Jatiyoso berpotensi mengalami bencana tanah longsor menengah hingga tinggi. Pada peta daerah yang menunjukkan kerawanan tinggi terdapat pada desa Wukirsawit, sebagian dari wilayah Desa Beruk, Tlogo dan Jatiyoso, sedangkan desa lainnya berpotensi mengalami bencana tanah longsor dengan kategori menengah. Keadaan topografi Kecamatan Jatiyoso yang kasar menyebabkan daerah ini terjal, sehingga sangat berpotensi mengalami bencana tanah longsor.

Peta Rawan Bencana Kecamatan Jatiyoso sesuai dengan wilayah yang dipetakan oleh BPBD Karanganyar, bahwa di Kecamatan Jatiyoso berdasarkan parameter-parameter kerawanan longsor termasuk salah satu kecamatan yang memiliki kerawanan yang tertinggi. 


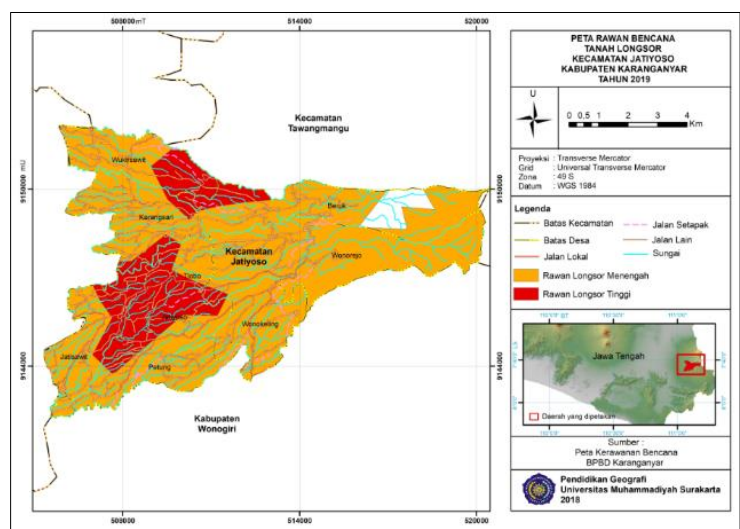

Gambar 3. Peta Rawan Bencana Kecamatan Jatiyoso

Daya tampung shelter berarti kemampuan shelter yang dapat digunakan untuk menerima atau kemampuan ditempati korban. Perhitungan daya tampung tersebut sesuai dengan pedoman United Nations High Commission of Refugees (UNHCR) kebutuhan ruang evakuasi sementara adalah $3.5 \mathrm{~m}^{2}$ per orang. Berdasarkan hasil perhitungan daya tampung fasilitas umum di Kecamatan Jatiyoso, menunjukan bahwa terdapat 5 kelas daya tampung. Kelas pertama sebanyak 15 - 42 jiwa, kelas kedua $43-74$ jiwa, kelas ketiga 75 - 110 jiwa, kelas keempat 111 - 213 jiwa, dan kelas kelima 214 -340 jiwa. Besaran kelas daya tampung tersebut menyebar disetiap desa secara keseluruhan (Gambar 4.).

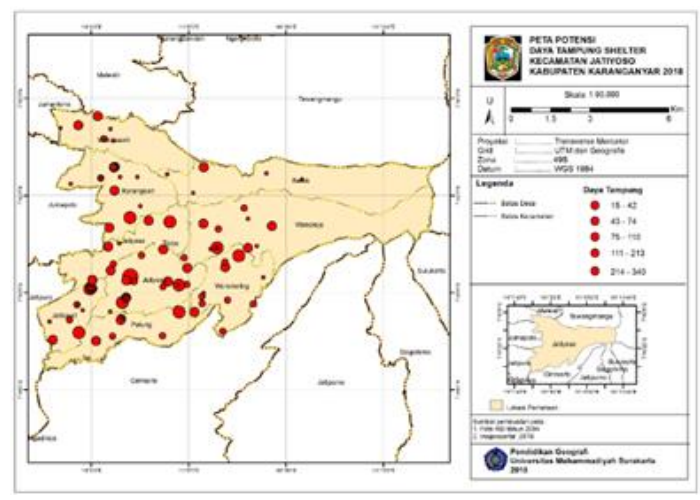

Gambar 4. Peta Potensi Daya Tampung Kecamatan Jatiyoso.
Berdasarkan hasil perhitungan, daya tampung di Kecamatan Jatiyoso dapat diketahui sebanyak 6.960 jiwa atau $16 \%$ penduduk dapat tertampung di pengungsian, sedangkan jumlah penduduk sebesar 36.465 jiwa. Berdasarkan hal itu, terdapat sebanyak 29.505 jiwa atau $84 \%$ penduduk tidak tertampung. Hal ini dikarenakan jumlah fasilitas peribadatan dan pendidikan yang masih terbatas, sehingga perbandingan jumlah penduduk dan fasilitas belum sebanding.

Sebaran fasilitas umum di Kecamatan Jatiyoso secara spasial merupakan mengelompok (cluster) di bagian barat berdasarkan referensi Yunus (2010). Permukiman idealnya harus memuat dua syarat utama yaitu, fisik lingkungan harus mencerminkan pola kehidupan dan pola budaya setempat, dan lingkungan permukiman harus didukung oleh fasilitas pelayanan dan ultilitas umumnya sebanding dengan ukuran atau luasannya lingkungan dan banyaknya penduduk. Oleh karena itu, kondisi permukiman tidak lepas dari aspek penduduknya sebagai penghuni RAH..

Berdasarkan sebaran permukiman di Jatiyoso yang penduduknya mengelompok di bagian barat, maka fasilitas peribadatan maupun fasilitas pendidikan pun terkonsentrasi di barat juga. Sebaran yang mengelompok dikarenakan wilayah barat lebih datar dibandingkan bagian timur yang berelief curam, orang akan cenderung memilih yang relatif datar sehingga fasilitas juga cenderung berada di area penduduk yang benyak. 
Tabel 2. hasil perhitungan daya tampung fasilitas umum di Kecamatan Jatiyoso

\begin{tabular}{|c|c|c|c|c|c|}
\hline Kecamatan & $\begin{array}{c}\text { Jumlah } \\
\text { Penduduk } \\
(\text { Jiwa })\end{array}$ & $\begin{array}{c}\text { Daya } \\
\text { Tampung } \\
(\text { Luas } \\
\left.\text { Atap/3.5 } \mathrm{m}^{2}\right)\end{array}$ & $\begin{array}{c}\text { Presentase } \\
\text { daya tampung } \\
(\%)\end{array}$ & $\begin{array}{c}\text { Penduduk } \\
\text { Tidak } \\
\text { Tertampung } \\
(\text { Jiwa })\end{array}$ & $\begin{array}{c}\text { Presentase } \\
\text { Tidak } \\
\text { Tertampung } \\
(\%)\end{array}$ \\
\hline Jatiyoso & 36.465 & 6.960 & 16 & 29.505 & 84 \\
\hline
\end{tabular}

Kerawanan longsor tinggi terdapat di 4 desa dengan total jumlah penduduk sebesar 16.511 jiwa. Tabel 3 menunjukkan jumlah penduduk desa yang dapat terpapar bencana tanah longsor pada daerah kerawanan tinggi. Keberadaan fasilitas umum untuk pengungsian di Kecamatan Jatiyoso berbeda-beda menyebabkan daya tampung tiap fasilitas berbeda. Daerah timur Kecamatan Jatiyoso tidak terdapat fasilitas pendidikan maupun peribadatan, dikarenakan sebagian besar wilayahnya terletak pada kemiringan yang terjal sehingga pembangunan fasilitas umum kurang intensif pada daerah itu.

Tabel 3. Perkiraan Desa Terpapar Kerawanan Bencana Tanah Longsor Kecamatan Jatiyoso

\begin{tabular}{|c|c|c|}
\hline No & Desa & $\begin{array}{c}\text { Jumlah } \\
\text { Penduduk } \\
\text { Rawan Terpapar } \\
\text { (Jiwa) }\end{array}$ \\
\hline 1 & Wukirsawit & 5660 \\
\hline 2 & Beruk & 4816 \\
\hline 3 & Tlobo & 2535 \\
\hline 4 & Jatiyoso & 3500 \\
\hline \multicolumn{2}{|c|}{ Jumlah } & 16511 \\
\hline
\end{tabular}

Penduduk desa di Kecamatan Jatiyoso tidak semua terpapar longsor, sehingga terdapat 4 desa yang berpotensi terpapar longsor yaitu di desa Wukirsawit, sebagian dari wilayah Desa Beruk, Tlogo dan Jatiyoso dengan total penduduk sebessar 16.511 jiwa. Padahal daya tampung keseluruhan sebanyak 6.960 jiwa (42\%), sehingga terdapat 9551 jiwa (58\%) yang tidak tertampung atau sebanyak penduduk tidak tertampung. Hal ini dikarenakan jumlah shelter yang tersedia terbatas baik jumlah maupun luasnya (Tabel 4).

Tabel 4. Perkiraan Shelter Pengungsian

\begin{tabular}{|c|c|c|c|c|}
\hline $\begin{array}{c}\text { Jumlah } \\
\text { Penduduk } \\
\text { Terpapar } \\
\text { (Jiwa) }\end{array}$ & \multicolumn{2}{|c|}{$\begin{array}{c}\text { Daya } \\
\text { Tampung } \\
\text { Shelter }\end{array}$} & \multicolumn{2}{|c|}{$\begin{array}{c}\text { Penduduk } \\
\text { Tidak } \\
\text { Tertampung }\end{array}$} \\
\cline { 2 - 5 } & $\mathrm{F}$ & $\%$ & $\mathrm{~F}$ & $\%$ \\
\hline 16511 & 6960 & 42 & 9551 & 58 \\
\hline
\end{tabular}

Penelitian ini didukung penelitian yang dilakukan oleh (Perdana \& Nugroho, 2017), bahwa berdasarkan standar dari UNHCR maka bisa ditentukan kebutuhan hunian untuk pengungsi adalah $3,5 \mathrm{~m}^{2}$ yang termasuk tempat menyimpan barang dan juga sirkulasi dalam hunian. Ukuran ini akan dijadikan sebuah modul untuk membentuk pola pengungsian di dalam ruang, menurut kaidah - kaidah standar kenyamanan ruang. Modul UNHCR dipilih dikarenakan memiliki tingkat kenyamanan dan efisiensi paling tinggi untuk tempat pengungsian serta memiliki kapasitas daya tampung yang relatif ideal.

\section{KESIMPULAN}

Kecamatan Jatiyoso memiliki sarana sekolah sebanyak 22 sekolah dan 69 sarana peribatan, dengan total luas atap sebesar $24360 \mathrm{~m}^{2}$. Berdasarkan hal tersebut, dihasilkan daya tampung sebesar 6960 jiwa, dengan jumlah penduduk yang terpapar sebesar 16.511 jiwa, sedangkan penduduk yang tidak tertampung sebesar 9551 jiwa. Diketahui sebanyak 6.960 jiwa atau $16 \%$ penduduk dapat tertampung di pengungsian, sedangkan jumlah penduduk sebesar 36.465 jiwa, maka dari itu sebanyak 29.505 (84\%) penduduk tidak tertampung. 


\section{DAFTAR PUSTAKA}

BPBD Karanganyar, Rekapitulasi Kejadian Bencana Di Kabupaten Karanganyar Tahun 2017.

Buletin Info Krisis Kesehatan, 2012, Manajemen Bencana dalam Kurikulum Mata Kuliah Poltekes, Karakteristik Krisis Kesehatan Akibat Bencana Tahun 2008-2011.

Fernando, R., Sujatmo, B., \& Hendri, A. (2017). Perencanaan Tempat Evakuasi Bencana Banjir Berbasis Teknologu Sistem Informasi Geografis (SIG) (Studi Kasus Kota Pekanbaru Kecamatan Rumbai). 4(1), 1-9.

Hadi Sabari Yunus. 2010. Metodologi Penelitian Wilayah Kontemporer. Yogyakarta: Pustaka Pelajar.

Hadi, W. Z., \& Hadiguna, R. A. (2016). Model Kebijakan Penetapan Institusi Masjid sebagai Shelter dalam Sistem Logistik Bencana di Kota Padang. Jurnal Optimasi Sistem Industri, 14(1), 16. https://doi.org/10.25077/josi.v14.n1. p16-32.2015.

Peraturan Kepala BNPB No. 02 Tahun 2012 tentang Pedoman Umum Pengkajian Risiko Bencana.

Perdana, A., \& Nugroho, A. M. (2017). Gedung Tempat Pengungsian Bersama Di Kabupaten Malang ( Studi Kasus : Gor Ganesha Kota Batu ). Jurnal Mahasiswa Jurusan Arsitektur, 5(4).

Prawiradisastra, S. (2008). Analisis morfologi dan geologi bencana tanah longsor di desa ledoksari kabupaten karanganyar. Sains Dan Teknologi Indonesia, 10(8), 84-90.
Setiadi, T. (2013). Perancangan Sistem Informasi Geografis Pemetaan Daerah Rawan Tanah Longsor, Mitigasi Dan Manajemen Bencana Di Kabupaten Banjarnegara. Jurnal Kesehatan Masyarakat (Journal of Public Health), 7(1), 33-42. https://doi.org/10.12928/kesmas.v7i1 .1050 .

Setiawan, H. (2014). Analisis Tingkat Kapasitas Dan Strategi Coping Masyarakat Lokal Dalam Menghadapi Bencana Longsor- Studi Kasus Di Tawangmangu, Karanganyar, Jawa Tengah. Jurnal Penelitian Sosial Dan Ekonomi Kehutanan, 11(1), 70-81. https://doi.org/10.20886/jsek.2014.1 1.1.70-81.

UNHCR. (2000), Handbook for Emergencies.

Yayasan Pengabdi Masyarakat (YPM) dan Japan International Cooperation Agency (JICA), 2011, Manual Evakuasi Darurat Bencana Banjir Bandang. 